\title{
How Jewish is Esther? Or: How is Esther Jewish? Tracing Ethnic and Religious Identity in a Diaspora Narrative
}

\author{
Anne-Mareike Wetter
}

(Universiteit Utrecht; a.wetter@uu.nl)

Perhaps the most fundamental question raised in discussions around the Masoretic text of Esther is whether it is a religious text. A second, closely related issue concerns the identity of the "Jews " or yehûdim we encounter in the book.

In this article, the initial focus is on the last question - how to understand $y^{e} h \hat{u} d \hat{\imath}(m)$ in the context of Esther. My answer is based on insights provided by ethnic theory. In the end, I hope to show that even in the seemingly a-religious masoretic text of Esther, ethnic identity cannot be separated from religious identity, despite many proposals to the contrary.

\section{Jew, Judabite, Judean?}

The issue at stake here can be summarized into one question: how to translate the term $y^{e} h \hat{u} d \hat{\imath}(m)$, which describes the group Mordecai and Esther belong to. Several options suggest themselves: Jew, Judahite/ Judean, or even »inhabitant or exile of the province Yehud «1? Whatever translation one chooses is central for one's understanding of the book of Esther, and of the branch of Diaspora Judaism it represents.

Most English translations render $y^{e} h \hat{u} d \hat{\imath}(m)$ in the book of Esther as "Jewish " or » Jews ", despite the absence of explicitly religious language throughout the book. ${ }^{2}$

\footnotetext{
1 Steve Mason, based on his analysis of the usage of the Greek and Latin equivalents of $y^{e}$ hudim in the centuries around the beginning of the Common Era, argues for translating the term as "Judaean « - not only in Esther, but in all documents from this period: "[T]he Ioudaioi / Iudaei of Graeco-Roman antiquity understood themselves, and were understood by outsiders, as an $\varepsilon \theta v o s$, a people comparable to and contrastable with other $\iota^{\prime} \theta \nu \eta$ « (S. Mason, Jews, Judaeans, Judaizing, Judaism: Problems of Categorization in Ancient History, JSJ 38 (2007), 457-512, 489).

2 E.g., NIV, NASV, KJV, ESV.
} 
Contrary to this trend to emphasize the religious content of $y^{e} h \hat{u}$ $d \hat{\imath}(m)$ in Esther, many biblical scholars conclude that "Esther seems to be Jewish in a sense more ethnic than religious ${ }^{3}$ or even that the Judaism found in Esther is »ethnic and no more. «4

I resist this interpretation for several reasons. First of all, it seems to be based on an "argument from silence «: just because there is no mention of God or any specifically religious customs in the book, the conclusion is drawn that $y^{e} h \hat{u} d \hat{\imath}(m)$ must be an ethnic label. Second, it presupposes a neat distinction between ethnic identity on the one hand, and religious identity on the other. However, even if we assumed that "ethnicity " and "religion " were well-defined concepts with a life outside the academy ${ }^{5}$, and that they could simply be applied to literary texts from a different time and a different place, the correlation between the two is complex to the extreme. To argue that ethnic identity is what is left when we take away religion is to oversimplify the intricate nature of group identity, and to ignore the ongoing discussion on precisely this issue in the social sciences.

3 C. A. Moore, Esther, AB 7b, 1971, xxii.

4 K. J. L. Larkin, Ruth and Esther, 1996, 61. Other examples are Adele Berlin and Sidnie White Crawford. Berlin, e.g., remarks that $y^{e}$ hudim »is an ethnic epithet " and that »Esther, like other Jewish Diaspora stories, strengthens the ethnic pride of Jews under foreign domination " (A. Berlin, Esther, The JPS Bible Commentary, 2001, 24, xxxv). White Crawford asserts that "Jewish identity in Esther is ethnic, and Jews can successfully hide that identity [...] The result is an extremely limited definition of what it means to be a Jew, a definition peculiar to the Hebrew edition of Esther « (S. White Crawford, Esther and Judith: Contrasts in Character, in: S. White Crawford / L. J. Greenspoon (eds.), The Book of Esther in Modern Research. 2003, 68. A more nuanced account can be found in Gerleman's commentary in the BKAT series. Gerleman reads Esther as a Diaspora-appropriation of the Exodus narrative, a »theologisch chiffriertes Dokument " (43), which, through literary parallels, defines the $y^{e}$ hûdim as YHWH's people without ever mentioning God himself.

5 Especially in post-colonial discourse, academic definitions of religion have been criticized as an invention of (post-)protestant Western thought. See, e.g., J. Smith, Imagining Religion: From Babylon to Jonestown, 1982; T. Asad, Genealogies of Religion: Discipline and Reasons of Power in Christianity and Islam, 1993; R. King, Orientalism and Religion: Post-Colonial Theory, India, and the Mystic East, 1999. As for ethnic identity, although it is generally acknowledged to be one of the primary organizing principles of human history "no one seems to understand very well how ethnicity works « (P. Spickard / W. J. Burroughs (eds.), We are a People: Narrative and Multiplicity in Constructing Ethnic Identity, 2000, 1). 


\section{Defining Ethnic Identity}

The book of Esther can be read as a construction site in which ethnic identity is given shape. I approach the narrative as an attempt to provide one possible answer to the question what is Yehudite identity in the face of prolonged (and voluntary) Diaspora. Searching the text for »ethnic markers ", I analyze what markers are present at all, how they are related to one another, and what role religion plays in this complex whole.

The set of "ethnic markers " used in my analysis comes from Hutchinson and Smith. They define an ethrie as:

"a named human population with myths of common ancestry, shared historical memories, one or more elements of common culture, which need not be specified but normally include religion, customs, or language, a link with a homeland, and a sense of solidarity among at least some of its members. « 6

I will attempt to trace each of these ethnic markers in the Esther narrative, with particular focus on the interplay between Mordecai, the epitome of "Jewishness ", and Haman, who threatens to annihilate Yehudite identity.

\section{Mordecai's Genealogy - Ethnic Identity in Nutshell}

It seems natural to turn to the character of Esther in an investigation of "Jewishness " in the book named after her. However, the girl Esther yields very little if we look for any of the ethnic markers spelled out by Hutchinson and Smith. She is never called $y^{e} h \hat{u} d \hat{\imath} t$, she successfully hides her Jewish background, her link with her »homeland « is very distant at best, and her solidarity with her people only shows after coercion from Mordecai.

Mordecai, on the other hand, is called a $y^{e} h \hat{u} d \hat{\imath}$ at least ten times, and I believe his introduction in Est 2,5 f. offers important hints about the connotations of $y^{e} h \hat{u} d \hat{\imath}$ in the book:

An ' $\hat{\imath} \zeta y^{e} h \hat{u} d \hat{\imath}$ was in the citadel Susa, and his name was Mordecai, son of Jair, son of Shimei, son of Kish, a Benjaminite, who had been exiled from Jerusalem during the exile that had taken place under Jeconiah, king of Judah, who had been taken into exile by Nebuchadnezzar, king of Babel.

Several characteristics of an ethnie as enumerated above become apparent: A name $\left(y^{e} h \hat{u} d \hat{\imath}\right)$, references to more or less mythical ancestors, shared historical memories, and a link with a homeland. I will treat each of these in turn, starting with the »mythical ancestors « found in the genealogy.

6 J. Hutchinson / A. D. Smith (eds.), Ethnicity, 1996, 6 f. 
Mordecai's genealogy is an eloquent example of the intertextual character of the book of Esther. Here, (alleged) biological and narrative inheritance - or »myths of common ancestry " and »shared historical memories" - intertwine. Yehûdim are those who belong to the same bloodline, and who share or at least understand the »historical memories " alluded to through this bloodline.

Mordecai's own name, with the theophoric element Marduk, "was a common name of the Persian period for both Jews and non-Jews $" 7$, and reflects the practice of Jews living in Diaspora to take over personal names from their surroundings. ${ }^{8}$ By contrast, the names forming Mordecai's genealogy firmly link him to the literary tradition of Israel. The author abandons historical plausibility in order to link Mordecai to two individuals from the early days of the kingdom of Israel/Judah: Kish and Shimei.

Kish is known as the father of Israel's first king, the Benjaminite Saul (I Sam 9,1). According to I Samuel 15, Saul's eventual defeat was not so much caused by the rise of David as by Saul's own disobedience to YHWH. Significantly, it is Saul's failure to wipe out the Amalekites, including their king Agag, that results in YHWH rejecting him as king.

Shimei makes his first appearance during the rebellion of Absalom, after David has fled from Jerusalem. Pelting the king and his officials with stones, Shimei exclaims: »Go out, go out, bloody man, worthless man! YHWH has caused all the blood of the house of Saul, in whose stead you reigned, to return to you. [...] And look, you are [caught] in your own wickedness, because you are a man of blood " (II Sam 16,7f.). Shortly before his death, the aging king David remembers Shimei and his offense. He charges Solomon to » bring down his [Shimei's] gray head to the grave in blood « (I Reg 2,9). The young king reminds Shimei of the "wrong you did to my father David ", and has him killed by one of his officials. Significantly, the account of Shimei's death is followed by the statement that »the kingdom was firmly established in the hand of Solomon « (I Reg 2,46). Apparently, Shimei was the last obstacle between Solomon and his throne.

Together, Kish and Shimei form a strong reminder of Israel's first king, and of a royal line that was cut short by the appearance of »bloody David «. ${ }^{9}$ Whatever the political implications may be, I want to emphasize that Mordecai's genealogy is concerned with two aspects of ethnic identity: not only "alleged common bloodline ", but also certain »shared historical memories", which it appropriates in a very uncommon way.

7 Berlin, Esther, 24.

8 See Moore, Esther, 19, for a summary of different positions regarding the meaning of Mordecai's name.

9 See also Y. Amit, The Saul Polemic in the Persian Period, in: O. Lipschits / M. Oeming (eds.), Judah and the Judeans in the Persian Period, 2006, 647-661. 


\section{The Shared Memory of Exile}

Although historically impossible, Mordecai is introduced as a member of the group that had been exiled from Jerusalem by Nebuchadnezzar. There are two ways to read this verse. One would be to focus on the homeland-aspect: »Judah « would then acquire a significance far beyond that of a geographic region: it would be the symbolic and longed for home of all yehîdim, the place where Yehudite identity is invented and maintained.

However, to read all this into Est 2,6 would ignore the general tenor of the rest of the narrative, where Judah, Jerusalem, or the idea(l) of return play no role whatsoever.

I believe the focus in this verse is on a different detail: the »shared historical memories " of exile and Diaspora. The verbal stem גלה (go into exile) occurs as often as four times in this one verse. This suggests that it is not geography that makes someone a $y^{e} h \hat{u} d \hat{\imath} t$, but rather the common experience of being deported. Beal, although not referring to ethnic theory, makes a very similar observation: "To be Jewish, is, in the book of Esther, to know exile as formative experience. «10 A positive appreciation of the Diaspora community as bearers of Yehudite identity is central to the book of Esther. The fact that Esther explicitly refers to the exiles taken under Jeconiah may be significant in this regard as well. After all, this group consisted of the educated elite, is responsible for producing and archiving the literary inheritance of the nation.

Summing up, in the introduction of Mordecai we find at least four features of an ethnie: a common name (yehidim), shared historical memories (both the hints at Saul's royal line and the experience of exile), and a tenuous link with a homeland. What we don't have here, nor, at first sight, anywhere else in the narrative, are "elements of common culture".

However, I believe there is more " common culture « in Esther than is visible at first glance - not in common rituals or customs, but in a very specific appropriation of Israel's past. This appropriation has everything to do with Haman, the archenemy of the yehîdim.

\section{»Blot out the Memory of Amalek«}

Haman is introduced as the representative of an ethnic group: he is »the son of Hammedatha, the Agagite «. This information is sparse: the reader is left to guess who the Agagites are, where they come from, and what their relations with the $y^{e}$ hiudim are. However, I think this "gap" is precisely the point here. The reader's knowledge of specific literary traditions is crucial not only to supply Haman with an ethnic background,

10 Beal, Hiding, 33. 
but also to understand Mordecai's refusal to bow down before him, and Haman's reaction to this refusal. ${ }^{11}$ Several narratives from the Torah and the Deuteronomistic history - in other words, narratives spanning the time from Israel's very beginnings to its more recent history - supply the missing links. Haman the Agagite traces his roots back to Agag, the king of the Amalekites whom Saul failed to kill in I Sam 15. And the narrative of I Sam 15, in turn, points back to the hostile encounter between the Amalekites and the Israelites during the desert wanderings. Ex 17,16, states that "YHWH will be at war against the Amalekites from generation to generation «. This harsh verdict is explained in Deuteronomy 25: »When you were weary and worn out, they met you on your journey and cut off all who were lagging behind; they had no fear of God « (Deut 25,18 ). Through this action, the Amalekites had placed themselves outside of human society, and did not deserve to be treated humanely. ${ }^{12}$ To destroy the Amalekites is turned into a religious duty in the next verse: "When YHWH your God gives you rest from all the enemies around you in the land he is giving you to possess as an inheritance, you shall blot out the memory of Amalek from under heaven. Do not forget! « This commandment takes the reader by surprise, both due to its content and to the context in which it is spoken. Deuteronomy 25 and the preceding chapters consist of a variety of rules pertaining to the organization of Israelite society in the Promised Land, ranging from issues concerning criminal and family law, to economy, to "animal rights «13. The commandment to remember and avenge the Amalekites' deeds seems misplaced in this context - and yet I think it is precisely this context that is significant for understanding the ethnic and perhaps also religious identity constructed in Esther.

The regulations enumerated in Deuteronomy 25 and the preceding chapters can be construed as a description of ideal Israelite culture both in the sense of common practices and of a shared belief system. After hav-

11 The conventional explanation is that Mordecai, as a Jew, would bow down only to God, and that his refusal is a sign for his obedience to the commandments of YHWH. Taking the opposite stance, Korpel claims that Mordecai's refusal can hardly be construed as an observance of Jewish/Israelite law or custom - paying homage to humans occupying a higher place in the hierarchy is never perceived as a problem in other biblical texts, and Persian kings were not perceived as deities, much less their advisors (M. C. A. Korpel, De Ester code, in: Annette Merz / Bob Becking [eds.], Verhaal als Identiteits-Code Vol. 60. Utrechtse theologische reeks, 2008, 189-205, 192). Read in this manner, Mordecai's behavior is a witness of his distance to the traditions of Israel rather than a proof of his Jewishness.

12 Benno Jacob calls their behaviour "gänzliche moralische Verderbtheit ", because they did not shrink back from attacking a people of refugees that were, at the time, on a religious pilgrimage (B. Jacob, Das Buch Exodus, 1997, $503 \mathrm{f}$.$) .$

13 See Deut 25,4 . 
ing spelled out the religious and cultic duties of the new nation in Deuteronomy $4-14$, the text turns to more mundane matters - the conditions upon which Israel is to build its daily life. To commemorate the misconduct of the Amalekites and its consequences here is to declare hatred of the Amalekites part of the culture of Israel. And although none of the other cultural markers spelled out in these chapters can be found in Esther, this one detail has been taken up and imbued with new life. »Israel « in Esther is not so much defined by means of specific modes of cultural and or ritual behaviour, but rather through its relationship with one specific (albeit imagined) other group. The fact that this particular group has been the enemy of Israel since before its establishment as a nation implies that the group defining itself as yehûdim in Esther cannot be conceived apart from the people of God as presented in the Deuteronomistic literature. The prediction that "YHWH will be at war against the Amalekites from generation to generation « $(\mathrm{Ex} 17,16)$ spans a bridge from Moses via Saul to Mordecai and Esther. Haman the Agagite is not simply an extraordinarily malicious individual, nor is he the representative of an existing ethnic group. He is Amalek and Agag resurrected, and it is the duty of any »Israelite " in general and a Benjaminite and heir of Saul in particular to stand up to him - and certainly not to bow down before him. Mordecai cannot help but defy Haman, and Haman cannot help but conspire against the yehôdim - his identity, firmly rooted in the narrative heritage forming the backdrop of Esther, demands it. ${ }^{14}$

On an even deeper and more general level, Haman is not »just « a second Amalek or Agag; he is the personification of the innate fear of annihilation, of the ultimate loss of identity. And Mordecai is not simply a second Moses or an all-improved Saul - he is the ideal Israelite who guarantees that this identity will survive, even under the most hostile circumstances. It is the Diaspora community, personified in Esther and Mordecai, that proves to be the most worthy bearers of »Jewish « tradition: They have not forgotten to blot out Amalek (Deut 25,19), and, unlike their forefathers, they have actually managed to perform the deed. Significantly, they do so without divine intervention.

14 Many commentators (e.g., Moore, Gerleman, Berlin) have spotted the link between Haman and earlier accounts of the Amalekites/Agagites. Few of them, however, point out the power play at work in the construction of Haman's identity from the perspective of the $y^{e}$ hûdim. In his »autobiography « of Haman, Philip Davies offers a playful and yet disturbing account of this phenomenon from the perspective of Haman (P. R. Davies, Haman the Victim, in: P. R. Davies (ed.), First Person. Essays in Biblical Autobiography, 2001, 137-154). 


\section{Conclusion}

Returning to my initial question - how to translate $y^{e} h \hat{u} d \hat{\imath}(m)$ in the book of Esther - the results are ambiguous. There are many ethnic markers defining the Yehudite community - but homeland is the least important of these. Thus, a geographically oriented translation such as "Judeans " or " Judahites « is not convincing. On the other hand, to translate the term as "Jews " would imply a correspondence between the yehûdim in Esther and specific other groups from later times and other contexts - a correspondence that may simply not exist. Of course, all of these groups share in the same literary heritage, but Esther appropriates this heritage in such a distinctive way as to set it apart from what most people today would define as " Jewish «.

No translation of $y^{e} h \hat{u} d \hat{\imath} m$ seems satisfactory, and yet translate we must. Taking everything into account, I tend towards rendering $y^{e} h \hat{u}$ $d \hat{\imath}(m)$ as Jews - not because the $y^{e} h \hat{u} d \hat{\imath} m$ in Esther conform to the image of Jewishness found in other biblical writings, or to our own ideas of what Jewishness is all about, but because I believe the book is an attempt to fill an ambiguous term with distinct meaning. The "Jews « in Esther may not fulfil our expectations, but they clearly think of themselves as the rightful heirs of the "Jewish « literary tradition, a tradition they appropriate on the one hand, and from which they emancipate themselves on the other.

One of the most debated issues pertaining to the masoretic text of Esther concerns the identity of the group referred to as $y^{e} h \hat{u} d \hat{\imath} m$. The following article applies insights from ethnic theory to the book of Esther in order to elucidate the use of the term in this specific context, and possible implications for the religious or a-religious character of the book.

La question de l'identité des soi-disant $y^{e} h \hat{u} d \hat{m} m$ dans le texte massorétique d'Esther est controversée. La présente étude fait intervenir des données ethnographiques afin d'éclairer d'un jour nouveau ce terme dans le contexte spécifique du livre d'Esther, abordant ainsi également la question du caractère religieux ou non-religieux du livre.

Die Identität der sogenannten $y^{e}$ hûdim im masoretischen Text von Esther ist ein kontroverses Thema. Der vorliegende Artikel setzt Erkenntnisse aus der Ethnologie ein, um neues Licht auf diesen Term im Kontext des Buches Esther zu werfen, und trägt damit letztendlich auch zur Diskussion über den religiösen Gehalt dieses Buches bei. 